\title{
EKOLOŠKE IZBEGLICE - (NE)REŠIV PROBLEM MEĐUNARODNE ZAJEDNICE
}

\author{
Nevena Šekarić \\ Univerzitet u Beogradu, Fakultet bezbednosti \\ Filip Stojanović \\ Centar za istraživanje javnih politika
}

\begin{abstract}
ako je kraj Hladnog rata sa sobom doneo mnoge promene u promi-
šljanjima o bezbednosti, pitanje zaštite životne sredine i negativni efekti njene degradacije postali su jedno od najznačajnijih. Klimatske promene, prirodne katastrofe, ali i delovanja čoveka na životnu sredinu, rezultovala su masovnim kretanjima ljudi sa pogođenih područja u potrazi za boljim načinom života. Ovakvi trendovi uslovili su pojavu ekoloških izbeglica, sve prisutniju na agendi međunarodne zajednice. Sa tim u vezi, u radu su dotaknuti najznačajniji elementi koji stoje u vezi sa ovom pojavom. Kao glavni izazovi koji stoje pred međunarodnom zajednicom u kontekstu rešavanja ovog pitanja istaknuti su nepostojanje opšteprihvaćene definicije ovog koncepta, kao i jedinstvenog pravnog okvira i politike kojima bi se upravljalo ovom pojavom na lokalnom, nacionalnom, regionalnom i međunarodnom nivou, zatim demografski i klimatski trendovi koji direktno utiču na intenziviranje ove pojave, nepostojanje jedinstvenih i sistematskih analiza i procena i mnogi drugi.
\end{abstract}

Ključne reči: ekološke izbeglice, međunarodna zajednica, uzroci ekoloških izbeglica, konflikti, životna sredina

Uvod

Deriod nakon Hladnog rata obeležila su nova bezbednosna kretanja u svetu. Nastajuća bezbednosna paradigma se sve više udaljava od tradicionalnog promišljanja bezbednosti u kontekstu vojnih pretnji i odbrane nacionalne teritorije. Naime, klasičnim vojno-političkim pretnjama pridružuje se široka agenda novih izazova koji svoje poreklo nalaze u ekonomskim, socijetalnim i ekološkim oblastima. Dinamika i raznolikost pojavnih oblika ovih izazova nesumnjivo proizvode negativne efekte po održivi razvoj i životnu sredinu.

Maltuzijansko gledište ${ }^{1}$ na svakodnevno povećanje broja svetske populacije u prvi plan ističe povezanost ove pojave sa degradacijom životne sredine. Naime, rast stanovništva ge-

\footnotetext{
${ }^{1}$ Tomas Robert Maltus (Thomas Robert Malthus), čuveni engleski ekonomista i demograf, zastupao je tezu da se broj stanovnika u svetu uvećava geometrijskom progresijom, a resursi aritmetičkom što je glavni uzrok bede i siromaštva.
} 
ometrijskom progresijom i problem održivosti resursa prouzrokuju velike promene u životnoj sredini. Drugim rečima, problem adekvatnog upravljanja životnom sredinom najizraženiji je u najnaseljenijim delovima planete. Usled negativnog delovanja na osnovne medijume životne sredine i kauzalanog odnosa među takvim pojavama, ljudi se više ne osećaju bezbedno i sigurno u svojim sredinama. Problemi poput suše, dezertifikacije, deforestizacije i sličnih ekoloških problema ${ }^{2}$, uticali su da ljudi masovno napuštaju sredine pogođene takvim pojavama i tako rezultovali novim fenomenom na globalnoj sceni - ekološkim izbeglicama. Ovakvi trendovi uticali su na to da se postojećem broju tradicionalnih (konvencionalnih) izbeglica ${ }^{3}$ pridružuje sve veći broj ljudi koji se mogu svrstati u kategoriju ekoloških izbeglica ${ }^{4}$ što je, između ostalog, rezultiralo i pokretanjem nemalog broja istraživanja na ovu temu.

Još 1995. godine, Majers i Kentova (Myers \& Kent) ukazali su na povećanje stope ekoloških izbeglica koje su primorane da napuste svoju sredinu zbog pogoršanja kvaliteta soli i vode (uključujući tu i dezertifikaciju, deforestizaciju i zagađenje), kao i klimatskih promena (uključujući suše, poplave i povećanje nivoa mora usled globalnog zagrevanja). Prema podacima ovih autora, 1995. godine barem 25 miliona ljudi pripadalo je kategoriji ekoloških izbeglica u poređenju sa 27 miliona konvencionalnih izbeglica (ljudi koji su bežali od političkog ugnjetavanja, religijskog progona i etničkih presija). Kao najrizičnija područja u kontekstu izvorišta ekoloških izbeglica pominju se Subsaharska Afrika (Sahel i Rog Afrike), indijski potkontinent, Kina, Meksiko i Centralna Amerika. Zabrinjavajuća procena autora da će se do 2010. godine (ako ne i pre) broj ekoloških izbeglica udvostručiti, pokazala se i više nego realnom [1].

Norman Majers (Norman Myers) u članku Environmental refugees: a growing phenomenon of the 21st century iz 2001. godine, ekološke izbeglice nazvao je "rastućim fenomenom XXI veka"[2]. Na godišnjem samitu američke Asocijacije za unapređenje nauke (AAAS) 2011. godine, profesorka Kristina Tirado (Christina Tirado) sa Univerziteta u Kaliforniji, iznela je zapažanje da ćemo, prema prognozi UN, do 2020. godine imati 50 miliona ekoloških izbeglica. Mnoge autore karakteriše mišljenje i da će masovne migracije ljudi uzrokovane klimatskim promenama proizvesti konflikte širom sveta, koji će imati negativne implikacije na različite segmente sistema bezbednosti. ${ }^{5}$ Naime, pažljivije analize međusobne povezanosti klimatskih promena i bezbednosnih implikacija, ukazuju da je

\footnotetext{
${ }^{2}$ Ekološki problemi u kontekstu bezbednosnih pretnji postali su predmet interesovanja naučne i političke javnosti početkom 90 -ih godina prošlog veka, sa afirmacijom koncepta ljudske bezbednosti koja u prvi plan postavlja bezbednost pojedinca i kvalitet života (za razliku od do tada dominantno državocentričnih promišljanja o bezbednosti). Sa tim u vezi, pionirskim potezom u kontekstu promovisanja ljudske bezbednosti smatra se Izveštaj Programa Ujedinjenih nacija za razvoj Nove dimenzije ljudske bezbednosti, objavljen 1994. godine.

${ }^{3}$ Prema izveštaju Visokog komesarijata Ujedinjenih nacija za izbeglice (UNHCR) za 2016. godinu, u svetu je do kraja 2016. godine postojalo 65,6 miliona prinudno raseljenih lica. U izveštaju se takođe navodi kako ova brojka vrlo lako može porasti, imajući u vidu da je do kraja 2014. godine bilo 15 miliona manje raseljenih lica. S obzirom na konstantan porast broja izbeglica, azilanata i interno raseljenih lica, povećanje iz godine u godinu je veoma izvesno. Izveštaj Visokog komesarijata za izbeglice dostupan je na sledećoj internet adresi: http://www.unhcr.org/dach/wp-content/uploads/sites/27/2017/06/2016_Global_Trends_WEB-embargoed.pdf

${ }^{4}$ Prema podacima Monitoring centra za interno raseljena lica (Internal Displacement Monitoring Centre) u prethodnih 10 godina, u svetu je bilo oko 203 miliona raseljenih lica usled prirodnih katastrofa. Ceo izvešta dostupan je na sledećoj internet adresi: http://www.internal-displacement.org/assets/publications/2016/2016global-report-internal-displacement-IDMC.pdf

${ }^{5}$ Neki od radova koji dovode u vezu ekološke migracije i konflikte su: (Adamson, 2006; Reuveny, 2007, 2008; Homer-Dixon, 2010; Ostojić, 2014, 2016; Orr et al., 2015).
} 
sukob između država malo verovatan, ali ne isključuju mogućnost izbijanja građanskih sukoba različitih društvenih grupa usled veliki migracijskih kretanja prouzrokovanih klimatskim promenama [3]. Osim toga, činjenica da je ugrožavanje životne sredine u mnogim strategijama nacionalne bezbednosti prepoznato kao ozbiljna pretnja, dodatno doprinosi tematizovanju ove teme u bezbednosnom kontekstu. ${ }^{6}$ Da veliko interesovanje za ovaj fenomen vlada na međunarodnom nivou, ističe i Fransoa Žemen (François Gemenne) navodeći kao prilog toj tvrdnji da je koncept ekološke migracije postao sastavni deo studija o migracijama, dok je broj istraživačkih projekata, radionica i konferencija na ovu temu značajno porastao tokom proteklih godina [4]. Imajući u vidu sve prethodno navedeno, može se zaključiti da ekološke izbeglice danas predstavljaju značajan bezbednosni problem i predmet pročavanja brojnih nacionalnih i međunarodnih subjekata.

Međunarodne organizacije poput UNHCR-a, Kancelarije za humanitarnu pomoć Evropske komisije (ECHO), brojne nevladine organizacije, organizacije civilnog društva, humanitarne organizacije, kao i akademska i stručna javnost, zainteresovani su za proučavanje i rešavanje ovog globalnog bezbednosnog fenomena. Međutim, iako postoji svest o ozbiljnosti problema, ova kategorija ljudi još uvek nema međunarodno priznat status što predstavlja prvi problem u pružanju adekvatnog odgovora međunarodne zajednice.

U tekstu koji sledi, najpre su predstavljeni akademski pokušaji i teškoće prilikom definisanja pojma ekoloških izbeglica. U drugom delu rada, rasvetljavaju se uzroci koji dovode do pojave ekoloških izbeglica, dok je treće poglavlje fokusirano na mogućnost nastanka konflikata kao jedne od posledica eskalacije ovog problema. Središte četvrtog dela rada čine budući trendovi rasta ekoloških izbeglica, dok se peti deo se odnosi na moguće opcije rešenja ovog problema. U poslednjem delu rada iznose se zaključna razmatranja.

\section{Pojmovno određenje ekoloških izbeglica}

Kretanje stanovništva, odnosno fenomen migracija, karakteristična je pojava ne samo XXI veka, već čitave istorije ljudske civilizacije. Činjenica je da su ljudi kroz istoriju godinama prelazili sa jedne na drugu teritoriju u potrazi za boljim uslovima života. Kada je reč o ekološkim izbeglicama, sam naziv upućuje na centralni element koji odlikuje ovu kategoriju - ekološki momenat, shvaćen u kontekstu degradacije životne sredine i klimatskih promena, jeste taj koji inicira kretanja ljudi u potrazi za kvalitetnijim životom. Drugim rečima, glavnu oblast interesovanja u vezi sa mogućim posledicama nove kategorije opisane kao „ekološke izbeglice" predstavljaju ekološki konflikti, prirodne nesreće, globalne klimatske promene i nesreće izazvane ljudskim faktorom[5]. Pritom je važno naglasiti da, pored procena o broju ekoloških izbeglica u svetu, variraju i definicije i tipologije takvih tokova.

Jovanović-Popović i Milinčić ističu kako je najpre neophodno pojmovno razgraničiti (ekološke) izbeglice i (ekološke) migranate. Prema ovim autorima, migrant je lice koje dobrovoljno napusti svoju zemlju kako bi se nastanilo na nekom drugom mestu - takvo lice može biti podstaknuto željom za promenom ili avanturom, iz porodičnog ili pak nekog drugog privatnog razloga. Suprotno tome, klasične izbeglice nemaju alternativu osim da

\footnotetext{
${ }^{6}$ Jedan od prvih autora koji je promovisao potrebu za integrisanjem ekoloških aspekata u bezbednosne strategije bio je Norman Majers (1989).
} 
traže izbeglički status negde drugde [5]. Shodno tome, izbeglički status podrazumeva postojanje nevoluntarističkog motiva, odnosno, takvog razloga za promenom životne sredine koji ne ostavlja izbora izuzev promene dotadašnjeg mesta življenja.

Dok se Lester Braun (Lester Brown) smatra autorom koji je među prvima popularizovao ovaj termin, prva zvanična definicija ekoloških izbeglica vezuje se za El-Hinavija (El-Hinnawi), objavljena u publikaciji pri Programu Ujedinjenih nacija za životnu sredinu (UNEP) 1985. godine. El-Hinavi ekološke izbeglice definiše kao ljude „koji su prinuđeni/primorani da napuste svoje tradicionalno mesto boravka/staništa, privremeno ili trajno, usled izraženih promena u životnoj sredini (prirodnih i/ili antropogenih) pri čemu im je ugroženo postojanje i/ili ozbiljno utiče na njihov kvalitet života“ [6]. U tom smislu razlikuje tri široke kategorije ekoloških izbeglica: 1) oni koji su privremeno izmešteni usled poremećaja u životnoj sredini, 2) oni koji su izmešteni za stalno i kojima je obezbeđeno novo mesto boravka i 3) oni koji migriraju sa svog izvornog mesta boravka, privremeno ili na stalnoj osnovi u potrazi za boljim životom (a ne usled ekonomskih razloga). ${ }^{7}$

Sa druge strane, Džodi Džejkobson (Jodi Jacobson) u radu iz 1988. Environmental refugees: a yardstick of habitability, nudi svoju tipologiju ovog fenomena i ekološkim izbeglicama smatra one: 1) koji su privremeno raseljeni zbog lokalnog poremećaja životne sredine, 2) koji su migrirali usled toga što degradacija životne sredine narušava njihovu egzistenciju ili predstavlja neprihvatljiv rizik po njihovo zdravlje i 3) koji su migrirali jer je degradacija zemljišta dovela do dezertifikacije i/ili drugih stalnih promena staništa [7].

U određenju pojma ekoloških izbeglica, Majers i Kentova navode kako u tu kategoriju spadaju „ljudi koji više nisu u mogućnosti da osiguraju bezbedan život u zemlji porekla zbog ekoloških faktora velikih razmera kao što su suša, dezertifikacija, krčenje šuma, erozija tla, nedostatak vode, klimatske promene, kao i prirodne nepogode u vidu ciklona, oluja i poplava. U ovakvim situacijama, ljudi uviđaju da alternative, osim da traže bolji život van datog područja, nema, bilo da se to odnosi na život unutar granica svoje zemlje ili van nje, bilo da je migracija privremena ili permanentna" [1]. Autori takođe ukazuju na neophodnost distinkcije između ekonomskih izbeglica i onih koji se mogu okarakterisati kao ekološke izbeglice, navodeći kako upravo ovakvo (ne)razlikovanje ekonomskih od ekoloških motiva predstavlja najveći izazov za međunarodnu zajednicu kada je u pitanju odnos prema ekološkim izbeglicama.

Osim akademskih nastojanja, i donosioci političkih odluka, kao i međunarodne organizacije koje se bave ovom tematikom, zainteresovani su za što preciznije određenje ovog pojma. Tako je Međunarodna organizacija za migracije (IOM) predložila širu radnu definiciju „ekoloških izbeglica“ kao „lica ili grupe lica koja su usled imperativnih razloga,

\footnotetext{
${ }^{7}$ Jedna od kritičara El-Hinavijeve definicije, Dajana Bejts (Diane Bates), ekološki sociolog, zastupa mišljenje da El-Hinaviju u definiciji nedostaje razlika između različitih grupa ekoloških izbeglica (Bates, 2002: 466). Ona, naime, smatra da je definicija veoma široka i da će tako mnoge grupe moći da budu klasifikovane kao ekološke izbeglice. S druge strane, Ostojić navodi kako El-Hinavi u svojoj definiciji ne pravi razliku između pojedinih vrsta ekoloških izbeglica pa tako ne razgraničava one koji su izbegli usled posledica zemljotresa ili cunamija i onih koji su postepeno napuštali ili će napuštati svoja mesta prebivališta zbog erozije, deforestacije, dezertifikacije ili povećanja nivoa mora (2016:358). Međutim, važno je istaći kako je El-Hinavijeva definicija prva koja je skrenula pozornost naučnika na ovu temu, kao i da su mnoge druge definicije ovog koncepta zadržale neke od elemenata El-Hinavijeve definicije.
} 
naglih ili progresivnih promena u okruženju koje negativno utiču na njihov život ili životne uslove, primorana ili izabrala da napuste svoje domove, bilo privremeno ili trajno, i koja migriraju u granicama svoje zemlje ili u inostranstvo" (Uvodno izlaganje Brunson MekKinlija, generalnog direktora IOM-a, na Konferenciji o klimatskim promenama, degradaciji životne sredine i migracijama, Ženeva, 19. februar 2008).

\section{Problemi u definisanju ekoloških izbeglica}

Postojanje velikog broja definicija ovog pojma i raznolikih tipologija problematizuje formiranje jedinstvene definicije pojma ekoloških izbeglica na međunarodnom nivou. Ostojić u svom članku Ekološke izbeglice: direktan ili indirektan put do konflikta (2014), smatra da je jedan od osnovnih razloga za ovakvo stanje to što u definisanju ovog pojma postoje različiti problemi koji nisu usko vezani samo za ekološke faktore, već zavise i od mnogih drugih činilaca. Naime, promene koje nastaju u životnoj sredini zavise od velikog broja elemenata, bilo da su oni nastali prirodnim putem (poplave, suše, zemljotresi, oluje i sl.) ili pod uticajem ljudskog nemara ili nepažnje (industrijski akcidenti, nuklearne katastrofe i sl.) ili kombinacijom oba navedena [8]. ${ }^{8}$ Poteškoća u definisanju ovog pojma leži i u određivanju da li je neko primoran da migrira ili se radi o dobrovoljnoj migraciji [9].

Nepostojanje opšteprihvaćene definicije ovog fenomena dodatno je opterećeno i paralelnom upotrebom različitih termina za označavanje pojave ekoloških izbeglica, poput izbeglica životne sredine, klimatskih izbeglica, kretanja stanovništva u kontekstu klimatskih promena i sl. Ono što je omogućilo široku upotrebu ovih pojmova jeste nepostojanje pravne baze, odnosno opredeljenost autora za upotrebu nešto srećnijih termina budući da prvobitni nije pravno utemeljen. No, bez obzira na to, ono što je zajedničko svim ovim pojmovima jeste direktna povezanost degradacije životne sredine sa potrebom za kretanjem stanovništva.

Činjenica da ne postoji opšteprihvaćena definicija ovog pojma problematizuje pitanje ekoloških izbeglica i adekvatnog odnosa međunarodne zajednice prema ovoj kategoriji ljudi. Ujedinjene nacije su 1951. godine u Ženevi usvojile Konvenciju o statusu izbeglica (Convention relating to the Status of Refugees), koja je dopunjena Protokolom iz 1967. Pomenuta Konvencija pod pojmom izbeglica podrazumeva sva ona lica „koja se zbog osnovanog straha od progona ili iz razloga rasne, verske, nacionalne ili pripadnosti određenoj grupi ili zbog političkog mišljenja, nalaze izvan zemlje svog državljanstva, pa ne

\footnotetext{
${ }^{8}$ Zanimljiva je bila debata koja se isprva vodila između tzv. maksimalista (onih koji su oštro promovisali konstrukt ekoloških izbeglica, odnosno ideju o direktnoj kauzalnoj vezi između promena u životnoj sredini i prinudnih kretanja stanovništva) i minimalista (kritičara prethodno pomenutog konstrukta). Naime, maksimalističku osnovu mišljenja krakterisao je tzv. linearni push-pull model degradacije životne sredine koji je podrazumevao da će ljudi usled negativnih promena u svom okruženju migrirati sa ekološko degradiranih mesta na mesta koja nisu u tolikoj meri ekološki degradirana. Sa druge strane, minimalisti su u tom kontekstu veću pažnju pridavali mnoštvu faktora koji podstiču migracije, poput istorijskih, političkih, ekonomskih i socijalnih. Kako navode $\mathrm{H}$ anter i dr., potonji su kritikovali maksimalistički pravac razmišljanja kao statičan, predeterminisan i neomaltuzijanski, ističući kako veza između promena u životnoj sredini i migracija nije ni direktna ni linearna (2015:384). Debata je kasnije u većoj meri promenila svoj čisto polarizovani karakter, na šta je uticao veliki broj studija koje su posvedočile o ekološkim uticajima na kretanja stanovništva.
} 
mogu ili ne žele, usled tog straha, da se stave pod zaštitu date zemlje..." [10] $]^{9}$ Kao što se može primetiti, Konvencija među glavnim uzrocima migracija ne prepoznaje njihovu ekološku dimenziju. S obzirom na ovakvo stanje stvari, određeni autori ističu kako je priroda ovakvih kretanja (pod uticajem klimatskih promena) depolitizovana. [4] ${ }^{10} \mathrm{U}$ cilju rešenja ovog pravnog problema, dominantna su bila dva stanovišta - prema prvom, potrebno je bilo izvršiti reviziju postojeće Konvencije tako da ona uključi i ekološki momenat [11] [12]; prema drugom, trebalo je podržati izradu ad hoc protokola ili konvencije koji bi prepoznali prava ekoloških izbeglica[13]. ${ }^{11}$ Međutim, iako međunarodno pravo ne poznaje ovu vrstu izbeglica (s obzirom da nemaju tretman izbeglih lica po međunarodnim klasifikacijama i merilima), navedeni problem je sve prisutniji u međunarodnoj javnosti [14].

Nepostojanje međunarodno prihvatljive definicije povlači za sobom i problem u vezi sa nadležnošću odgovarajuće međunarodne institucije koja bi se bavila ovom problematikom. U tom smislu, za kreatore politike je vrlo značajno da znaju kakva prava takva osoba ima - ekološke izbeglice nisu jasno prepoznatljiva kategorija te stoga ne mogu dobiti odgovarajuću pomoć. Drugim rečima, bez precizne definicije, praktičari i kreatori politike imaju poteškoća u pravljenju planova i postizanju željenog napretka u cilju rešenja ovog problema. lako UNHCR pomaže vrlo širokom krugu ugroženih ljudi, u najvećem broju slučajeva, kada je reč o licima koja su migrirala usled degradacije životne sredine, nema adekvatnog pravnog odgovora. ${ }^{12}$ Međutim, priznavanjem statusa ekoloških izbeglica, nastali bi brojni problemi finansijske prirode (tiču se pre svega ograničenih budžetskih sredstava za pomoć ovim licima), problemi koji bi se ogledali u pojavi velikog broja azilanata u sistemu UN, kao i problemi u razvijenim državama koje se danas suočavaju sa velikim prilivom migranata. Poslednjih godina migraciona politika mnogih država, a pogotovo visokorazvijenih, sve više postaje strogo restriktivna [8]. Sa druge strane, (ne)reago-

\footnotetext{
${ }^{9}$ Takođe, u akademskoj zajednici vode se rasprave oko toga da li je ekološki izbeglica lice koje je, usled ugrožavanja životne sredine, napustilo svoju zemlju ili je privremeno ili stalno migriralo na teritoriju koja se nalazi u okviru zemlje čiji je državljanin. Prema međunarodnom pravu, lica koja su napustila svoje prebivalište privremeno se nastanila na druge lokacije unutar svoje zemlje nazivaju se interno raseljena lica, što definitivno nije u koliziji sa uslovima koje propisuje Konvencija o statusu izbeglica za dobijanje izbegličkog statusa. Dakle, u pitanju se dve različite pravne kategorije - za postojanje izbegličkog statusa, prema Konvenciji, potrebno je da je lice ispunilo tri uslova: da je izbeglo iz svoje države, da ne želi da se vrati nazad i da je razlog takvom nevraćanju strah od progona. Sa druge strane, El-Hinnawi i Myers, čija teorija je trenutno najprihvaćenija, prekogranične migrante i interno raseljena lica koja mesto prebivališta menjaju iz ekoloških razloga nazivaju ekološkim izbeglicama (prema: Dun, Olivia V., and François Gemenne. (2008). „Defining environmental migration: Why it matters so much, why it is controversial and some practical processes which may help move forward". Revue Asylon (s), (6)).

${ }^{10}$ Naime, kako je već pominjano, centralni element koncepta izbeglištva jeste da lice okarakterisano kao izbeglica beži od progona ili da se plaši istog. U kontekstu zalaganja za korišćenje termina ekoloških izbeglica (i pored pravnih poteškoća) Žemen iznosi ideju kako klimatske promene zapravo predstavljaju jedan vid progona protiv najugroženijih i da je migracija izazvana klimatskim promenama veoma politička stvar, a ne čisto ekološka (2015:71).

${ }^{11}$ Ovakve ideje su uglavnom kritikovane isticanjem stava da se za većinu ekološki indukovanih migracija može očekivate da će se realizovati unutar nacionalnih granica (Tacoli, 2009), odnosno da će takvi narativi olakšati sekuritizaciju migracija u zemljama destinacije (Bettini, 2013; Hartmann, 2010).

12 Od 1986. godine, pored "konvencionalnih" izbeglica, UNHCR pruža pomoć i drugim kategorijama raseljenih ili siromašnih lica, uključujući i azilante i interno raseljena lica. Međutim, za sve one ljude koji su postali migranti zbog prirodnih katastrofa, pomoć ove organizacije još uvek nije dostupna.
} 
vanje međunarodne zajednice povodom ovog problema rezultira brojnim bezbednosnim, socijalnim i zdravstvenim problemima, ali povlači i moralne osude. U tom smislu, jasno je da se pred međunarodnom zajednicom nalazi prilično kompleksan izazov čije rešenje nije ni najmanje jednostavno.

\section{Uzroci pojave ekoloških izbeglica u svetu}

U cilju identifikovanja ljudi kao ekoloških izbeglica, neophodno je najpre utvrditi najrelevantnije uzroke koji dovode do antropopresije i određene ekosisteme čine neadekvatnim za život. Drugim rečima, razumeti kretanja ljudi pod pritiskom environmentalne degradacije, znači proučavati element nestabilnosti u životnoj sredini. Tako Ivan Vlahos (Evan Vlachos) identifikuje određene kategorije ekoloških izbeglica kroz sledeće uzroke ekoloških migracija:

1. eko-metabolizam, ili promene ekosistema uključujući degradaciju zemljišta, prirodne resurse, globalno zagrevanje, dezertifikaciju, klimatske anomalije i sl;

2. nesreće uzrokovane ljudskim faktorom, uključujući industrijske nesreće, deforestaciju, devastaciju glavnih rečnih tokova, eksploataciju resursa i sl;

3. ekološko-politički potresi, uključujući propadanje režima, konfrontacije, ratove, revolucije, iščezavanje granica i

4. sociološko-ekonomska dislokacija uključujući pomeranja u međunarodnoj ekonomiji i neprikladne strategije razvoja, oskudicu resursa, pristup resursima, društvena previranja [15].

Posmatrano sa kritičkog aspekta, navedena klasifikacija u neku ruku ostaje nejasna. Naime, ovi faktori se prepliću i ne postoji jasna razlika između ekoloških, ekonomskih, političkih ili socijalnih kriterijuma koji bi pomogli u klasifikaciji sadašnjih i budućih ekoloških izbeglica. Dejana Dimitrijević obrazlaže predloženu klasifikaciju argumentom da „eko-metabolizam, nesreće uzrokovane ljudskim faktorom, ekološko-politički potresi i sociološko-ekonomska dislokacija nesumnjivo predstavljaju pojednostavljeni opis tipologije što sažima značajne ekološke kategorije, koje se često prepliću“ [15].

Sa druge strane, Šin-va Li (Shin-wha Lee), nakon tabelarnog prikaza tipologije ekoloških promena kao uzroka izmeštanja stanovništva ${ }^{13}$ koju smatra preopširnom za korišćenje, navodi dve velike grupe uslova koji uvećavaju i ubrzavaju efekte ekoloških promena, što izaziva kretanje populacije iz ugrožene oblasti ekološke bezbednosti, čime oni postaju ekološke izbeglice.

U prvu veliku grupu faktora Šin-va Li ubraja naglašavajuće uslove - klimatske, odnosno geofizičke faktore - sve one faktore na koje čovek ne može da utiče niti da ih kontroliše. U drugu grupu, Li ubraja olakšavajuće uslove (koji zapravo predstavljaju antropogene uticaje), a koji se dele na:

- uplitanje ljudi u prirodne tokove (Povećanje broja ljudi na planeti imalo je za posledicu uvećanje intenziteta ljudskih aktivnosti kojima je čovek uticao na mnoge prirodne tokove. Klimatske promene, kao rezultat čovekovih aktivnosti, tako dovode do pojave suša,

\footnotetext{
${ }^{13}$ Videti detaljnije u: Lee, S.-wha (1997). In Limbo: Environmental Refugees in the Third world. Conflict and $t$ he Environment, 33, 273-292.
} 
oluja, poplava i drugih prirodnih nesreća. Krčenje šuma, zagađenje vode i vazduha uzrokuju degradaciju zemljišta što opet dovodi do ubrzavanja pojedinih prirodnih nesreća.);

- nedelovanje vlade (neznanje, korupcija ili neodgovornost vlada određenih država, zbog čega iste nisu mnogo učinile da predvide situacije u kojima može doći do nastanka ekoloških izbeglica);

- delovanje vlade (svi oni postupci vlade država koje su svojim radom omogućile da dođe do ekonomskog razvoja države, pri čemu je došlo do realizacije velikih infrastrukturnih projekata u sektoru energetike, navodnjavanja i sl, pod čijim je uticajem došlo do premeštanja i ponovnog naseljavanja stanovništva) i

- međunarodni faktori (uglavnom se ogledaju u međunarodnoj pomoći razvijenih država zemljama Trećeg sveta u vidu finansijskih sredstva i tehničke pomoći).

Da bi se lica smatrala ekološkim izbeglicama, Li navodi kako kumulativno moraju biti ispunjena dva sledeća uslova: 1) da su interno izmeštena ili prinuđena da pređu granicu usled nesreća koje ugrožavaju njihove živote, prirodnih ili nesreća koje su u direktnoj vezi sa ljudskom aktivnošću ili direktno ugrožena ekocidom ili neprikladno vođenim programima razvoja i 2) da imaju malo izgleda za rehabilitaciju ili ponovno naseljavanje, što je direktna posledica nesposobnosti njihovih vlada da sprovode odgovarajući menadžment u slučaju nesreća ili bi pak rehabilitacija ili ponovno naseljavanje bili usmereni protiv njih [16].

Nešto novija viđenja uzroka ekološki indukovanih migracija uključuju promenu okvira kroz koji su se posmatrala kretanja stanovništva pod uticajem klimatskih promena i degradacije životne sredine. Naime, poslednjih nekoliko godina primetno je posmatranje ove pojave kroz afirmaciju diskursa koji počivaju na ideji strategije prilagođavanja i otpornosti (eng. resilience). Drugim rečima, ideja da kretanje stanovništva usled posledica ugrožavanja životne sredine predstavlja legitimnu strategiju prilagođavanja uveliko je uzela maha, svedočeći na taj način o delimičnom, ali ne zanemarljivom premeštanju migracija iz domena bezbednosti i upravljanja vanrednim situacijama u oblast razvoja [17] [18]. U tom kontekstu, primetno je smeštanje debate o ekološki indukovanom kretanju ljudi unutar šireg trenda priče o otpornosti u diskursima međunarodne politike, nečemu što se manifestuje u vidu narativa „migracija kao prilagođavanje“.

\section{Ekološke izbeglice i konflikti}

Kao što se do sada moglo videti, brojne prognoze u vezi sa potencijalnim brojem ekoloških izbeglica u budućnosti nisu nimalo optimistične. Sternov izveštaj sa velikom verovatnoćom prognozira da će do kraja XXI veka u svetu nastati oko 200 miliona novih ekoloških izbeglica potaknutih da napuste mesto boravka usled degradacije životne sredine. U srži ovakvih predviđanja nalazi se jednostavan uzročni model koji podrazumeva da će klimatske promene rezultovati nedostatkom resursa što će posledično dovesti do migracije, kao i nasilnih konflikata [19]. Pritom se procenjuje da će do najvećeg broja ovih izbeglica doći zbog porasta nivoa mora i pojave ekstremnih poplava i suša. Ekološke izbeglice se neretko naseljavaju na područja u kojima je već nastanjeno stanovništvo druge nacionalnosti, drugih običaja i tradicije, što kasnije dovodi do sukoba koji mogu da prerastu u oružane sukobe, pa čak i ratove [14]. Osim toga, Druri i Olson (Drury \& Olson) zaključili su da iznenadni stres u životnoj sredini može, pod određenim društvenim uslovima, biti katalizator za produ- 
bljivanje socijalnog raslojavanja i sukoba [20]. U tom kontekstu, sa bezbednosnog aspekta je vrlo značajno razmotriti vezu između ekoloških izbeglica i mogućih konflikata i njene implikacije kako po nacionalnu, tako i međunarodnu bezbednost.

U osnovi promišljanja o bezbednosnim implikacijama klimatskih promena nalazi se ideja da će se kratkoročni i srednjoročni adaptivni kapaciteti mnogih država naći pod pritiskom usled klimatskih promena što potencijalno dovodi do destabilizacije i nasilja, ugrožavajući nacionalnu i međunarodnu bezbednost, osim ako se odlučno ne reaguje [21] [22]. Dodatna zabrinutost povodom ovog pitanja proističe iz stava da bi klimatske promene mogle produbiti postojeće linije podele i sukoba u međunarodnim odnosima ukoliko međunarodna zajednica ne usvoji dinamičnu i globalno koordinisanu klimatsku politiku[19]. Kada se tome pridruže i različiti interesi dražava povodom ovog pitanja, u smislu postojanja onih koje su najodgovornije za klimatske promene i onih koje su njima najpogođenije, jasno je kakve implikacije po međunarodni mir i bezbednost može imati razjedinjenost u rešavanju ovog problema.

Kako Tepavac ističe, ekološke izbeglice, nakon ekološke katastrofe, potaknute za naseljavanjem novih lokacija, naseljavaju one delove koji su najbogatiji prirodnim resursima i koji omogućavaju lakši i sigurniji početak „novog života”, što u nekim situacijama uzrokuje prenaseljenost nekih teritorija i narušavanje balansa čovek - prirodni resursi, domicilnog stanovništva [14]. Naime, „Ovakvi slučajevi neretko dovode do lokalnih netrpeljivosti i sukoba koji mogu da prerastu u ozbiljne oružane sukobe sa ogromnim ljudskim i materijalnim žrtvama. U takvim slučajevima lokalno stanovništvo vrši razne vrste pritisaka kako bi se izbegla lica vratila u područja koja su usled ekoloških razloga napustila“ [14]. U prenaseljenim područjima, postoji velika opasnost od intenziviranja sukoba oko osnovnih resursa (npr. vode, hrane, obradivog i dostupnog zemljišta). U tom kontekstu, određeni autori smatraju da postoji više scenarija prema kojima klimatske promene i degradacija živtne sredine mogu doprineti otpočinjanju i jačanju nasilnih sukoba, poput pogoršanja kapaciteta vladinih formalnih i neformalnih institucija (u odgovoru na ovaj problem) i povećanja horizontalne nejednakosti među grupama [23] [19]. Da ovakva kretanja stanovništva mogu povećati konflikte u tranzitnim oblastima i odredištima smatra i Pavlović i naročito potcrtava kako pojedine države (one koje su ekstremno podložne klimatskim promenama) već pozivaju na međunarodno priznanje ovakvih, ekološki pokrenutih migracija [24].

Tematizujući vezu između ekoloških izbeglica i mogućih konflikata koje ova pojava može prouzrokovati, pokrenuto je nekoliko istraživačkih studija u cilju ispitivanja postojanja takve kauzalne veze. ${ }^{14}$ Sa druge strane, akademsku tematizaciju linka između klimatskih promena, kretanja stanovništva i sukoba uglavnom je karakterisala kritika takve veze budući da su teorijska osnova i empirijska podrška shvatanjima o direktnoj povezanosti ekoloških migracija i nasilnih konflikata bila prilično tanka. Stoga akademsku debatu uglavnom karakteriše skepsa prema ovom pitanju što znači da se ne treba zadovoljiti jednostavnim zaključcima, već potencijalne veze između klimatskih promena, degradacije životne sredine, migracija i sukoba posmatrati kao kompleksne, nastojeći da se na sveobuhvatan način priđe ovom problemu sagledavanjem svih relevantnih aspekata.

\footnotetext{
${ }^{14}$ Za više pogledati sledeće radove: 15. Raleigh, C. (2010). Political marginalization, climate change, and conflict in African Sahel states. International Studies Review, 12, 69-86; Raleigh, C., Linke, A., Hegre, H., \& Karlsen, J. (2010). Introducing ACLED: An armed conflict location and event dataset: Special data feature. Journal of Peace Research, 47, 651-660; Reuveny, R, Climate change-induced migration and violent conflict, Political Geography, 26 (6), 2007, 656-673.
} 
Akademska istraživanja o mogućoj vezi između životne sredine i konflikata započela su tokom 80-ih godina prošlog veka, kao deo studija mira i sukoba, počivajući na ideji o degradaciji životne sredine i oskudici obnovljivih resursa kao uzrocima nasilnih sukoba. U tom kontekstu, mnogi istraživači su došli do značajnijih dokaza da ovi faktori (degradacija životne sredine i oskudica resursa) mogu, u kombinaciji sa drugim „okidačima“ sukoba (poput etničke polarizacije, slabih političkih struktura i niskim nivoom ekonomskog razvoja) povećati verovatnoću izbijanja nasilnog sukoba. Shodno tome, nasilni sukobi su očekivani u onim oblastima koje prihvataju ekološke izbeglice, a koje karakteriše nedostatak stabilnih političkih struktura i institucija koje bi na adekvatan način upravljale oskudicom resursa.

Jedna od takvih studija jeste studija Rafaela Ruvenija (Rafael Reuveny) koji u svom delu Climate change-induced migration and violent conflict (2007) smatra da priliv ekoloških izbeglica u oblasti koje ih prihvataju može dovesti do sukoba različitog intenziteta. U tom smislu, on navodi pet osnovnih uzroka koji su doveli do pojave sukoba kao posledice pojave ekoloških izbeglica:

1. Konkurencija. Dolazak velikog broja ekoloških izbeglica u određenu oblast dovodi do pritisaka na ekonomiju i raspoložive resurse te oblasti. Takvi pritisci će rasti paralelno sa rastom broja migranata, a posebno u onim oblastima u kojima su raspoloživi resursi oskudni i gde imovinska prava nisu dovoljno razvijena. Povećana potražnja za resursima takođe može generisati prelivanje ekonomskih i političkih aktivnosti izvan državne granice u cilju sticanja sredstava, što povećava rizik od sukoba.

2. Etničke tenzije. U slučaju kada ekološke izbeglice i lokalno stanovništvo pripadaju različitim etničkim grupama, postoji opasnost od pojave konflikata. Lokalno stanovništvo se može osećati ugroženim, zemlje "domaćini“ mogu strahovati od separatizma, ekološke izbeglice mogu pokušati da se ujedine sa matičnom državom što potencijalno dovodi do agresivne reakcije autohtonog stanovništva. Posebno su kritične one oblasti gde je ova razlika veoma izražena, što dovodi do dugogodišnjih etničkih sporova, koji veoma lako mogu da prerastu u sukobe.

3. Nepoverenje. Osnovni kamen spoticanja ovde ogleda se u nepostojanju poverenja po pitanju motiva pojave ekoloških izbeglica u oblasti u koju dolaze. Npr. država koja prima izbeglice može iskazati nepoverenje jer smatra da druga strana putem ekoloških izbeglica pokušava da ostvari latentne interese (poput uspostavljanja etničke ravnoteže ili otcepljenja dela teritorije zemlje „domaćina“).

4. Greška linije. Sukobi mogu nastati zbog određenih grešaka na društveno-ekonomskoj liniji. Primer ove tvrdnje mogu biti kompetitivne pretenzije ekoloških izbeglica i autohtonog stanovništva u kontekstu raspoloživih radnih mesta.

5. Pomoćni uslovi. Ovaj uzrok dovodi do konflikta u onim državama koje prime veći broj ekoloških izbeglica, a čije ekonomije i resursi ne mogu da zadovolje potrebe ovako nastale uvećane populacije. Ovi regioni, odnosno države, najčešće su politički nestabilna područja, što povećava verovatnoću nastanka sukoba [25].

Ruveni navodi 38 slučajeva pojave ekoloških izbeglica u periodu od kraja pedesetih godina do danas u kojima je došlo do konflikta. Ove konflikte klasifikuje prema intenzitetu u četiri nivoa: konflikti niskog intenziteta (kod kojih praktično nema nasilja), srednji ili poluorganizovani konflikti, konflikti visokog intenziteta (unutrašnje pobune i međudržavne napetosti praćene oružanim nasiljem) i konflikti veoma visokog intenziteta (unutrašnji konflikti ili rat među državama). 
U prvom delu rada, Ruveni navodi 19 slučajeva kod kojih su ekološke migracije dovele do sukoba, od kojih se najveći broj konflikata desio se na prostoru Afrike (10 slučajeva), zatim Azije i Severne Amerike (3 slučaja) i po jedan u Okeaniji, Srednjoj Americi i Južnoj Americi. U drugom delu rada, Ruveni navodi ostalih 19 slučajeva u kojima je došlo do konflikta, ali bez primene sile. Osnovni faktori koji su doveli do pojave ekoloških izbeglica u navedenim slučajevima su degradacija zemljišta, suše, krčenje šuma, nestašica vode, poplave, oluje i glad. Takođe, analizom navedenih podataka vidi se da u 19 od 38 slučajeva (iako je došlo do konflikta) nije bilo značajnijih oružanih sukoba [25]. Naime, analiza pokazuje da su sukobi manjeg intenziteta u onim regionima i državama u kojima su starosedeoci i novopridošli migranti iste nacionalnosti, vere i etničke pripadnosti. Drugim rečima, starosedeoci lakše prihvataju one pridošlice koje su iste vere. Oružani sukobi, sa druge strane, nastali su u onim regionima koji su nerazvijeni i oskudni osnovnim resursima neophodnim za normalan život stanovništva.

Brzoska i Fröhlich (2016), smatrajući kretanje stanovništva samo jednim od mogućih odgovora na klimatske promene i degradaciju životne sredine, razlikuju četiri migracijska obrasca kada je reč o konekciji između migracija i posledica klimatskih promena: ekološko-ekonomski migranti, izbeglice usled klimatskih katastrofa, trajne klimatske izbeglice i migranti pogođeni menjanjem klime. Ne upuštajući se u njihovo detaljnije objašnjavanje, u nastavku je predstavljen tabelarni prikaz faktora rizika od izbijanja nasilnih sukoba prilikom kretanja iz siromašnih u razvijenije oblasti, u zavisnosti od različitih tipova pomenutih obrazaca i tipova mogućih konflikata izazvanih ekološkim migracijama.

\begin{tabular}{|c|c|c|c|c|}
\hline Tip & Sukobi interesa & Sukobi identiteta & Procesi sukoba & $\begin{array}{c}\text { Verovatnoća nasilnih } \\
\text { sukoba }\end{array}$ \\
\hline $\begin{array}{l}\text { Ekološko- } \\
\text { ekonomski } \\
\text { migranti }\end{array}$ & $\begin{array}{l}\text { Sukobi oko } \\
\text { mogućnosti } \\
\text { zapošljavanja }\end{array}$ & $\begin{array}{l}\text { Kretanja ka } \\
\text { područjima sa } \\
\text { jakim i } \\
\text { suprotstavljenim } \\
\text { identitetima }\end{array}$ & $\begin{array}{l}\text { Diskursi o „drugom“ } \\
\text { u prijemnim } \\
\text { područjima }\end{array}$ & $\begin{array}{l}\text { Generalno niska, izuzev u } \\
\text { područjima sa jakim } \\
\text { identitetima i diskursima o } \\
\text { „drugom“ }\end{array}$ \\
\hline $\begin{array}{l}\text { Izbeglice } \\
\text { usled } \\
\text { klimatskih } \\
\text { katastrofa }\end{array}$ & $\begin{array}{l}\text { Sukobi oko } \\
\text { resursa tamo gde } \\
\text { su ograničeni i } \\
\text { humanitarne } \\
\text { pomoći koja je } \\
\text { oskudna ili je } \\
\text { nema }\end{array}$ & $\begin{array}{l}\text { Masovni pokret ka } \\
\text { područjima } \\
\text { naseljena } \\
\text { grupama } \\
\text { neprijateljskog } \\
\text { identiteta }\end{array}$ & $\begin{array}{l}\text { Klimatske katastrofe } \\
\text { utiču na entitete } \\
\text { uključene u nasilan } \\
\text { sukob }\end{array}$ & $\begin{array}{l}\text { Niska, zbog široko } \\
\text { rasprostranjene } \\
\text { humanitarne pomoći i } \\
\text { redukovanih sposobnosti } \\
\text { za organizovanjem nasilja }\end{array}$ \\
\hline $\begin{array}{l}\text { Trajne } \\
\text { klimatske } \\
\text { izbeglice }\end{array}$ & $\begin{array}{l}\text { Sukobi oko } \\
\text { resursa, } \\
\text { mogućnosti } \\
\text { zapošljavanja }\end{array}$ & $\begin{array}{l}\text { Kretanja ka } \\
\text { područjima sa } \\
\text { jakim i } \\
\text { suprotstavljenim } \\
\text { identitetima }\end{array}$ & $\begin{array}{l}\text { Diskursi o } \\
\text { ekonomskoj } \\
\text { kompetenciji i } \\
\text { „drugom“ u } \\
\text { prijemnim } \\
\text { područjima }\end{array}$ & $\begin{array}{l}\text { Zavisi od intenziteta } \\
\text { sukoba oko interesa i } \\
\text { sukoba identiteta }\end{array}$ \\
\hline $\begin{array}{l}\text { Migranti } \\
\text { pogođeni } \\
\text { menjanjem } \\
\text { klime }\end{array}$ & $\begin{array}{l}\text { Sukobi oko } \\
\text { resursa }\end{array}$ & Sukobi identiteta & $\begin{array}{l}\text { Zavisni od } \\
\text { odsustva/prisustva } \\
\text { institucija koje } \\
\text { upravljaju sukobima }\end{array}$ & $\begin{array}{l}\text { Zavisi od intenziteta } \\
\text { sukoba i } \\
\text { odsustva/prisustva } \\
\text { institucija koje upravljaju } \\
\text { sukobima }\end{array}$ \\
\hline
\end{tabular}

\footnotetext{
${ }^{15}$ Za razumevanje načina na koji migracije mogu voditi nasilnim konfliktima, ovi autori koriste jednostavan model porekla nasilnih konflikata koji uključuje percepcije, interese i identitete.
} 
Grupa autora, ispitujući trendove, uzroke i izazove pojave ekoloških izbeglica u podsaharskoj Africi i njihovu vezu sa oružanim konfliktima, mišljenja je da su borba za oskudne resurse, etnički i politički rivalitet glavni uzroci građanskih ratova uzrokovanih kretanjem ekoloških izbeglica u ovom regionu [26]. Shodno tome, dali su shematski prikaz uloge ratova nastalih kao posledica kretanja ekoloških izbeglica na ovom području.

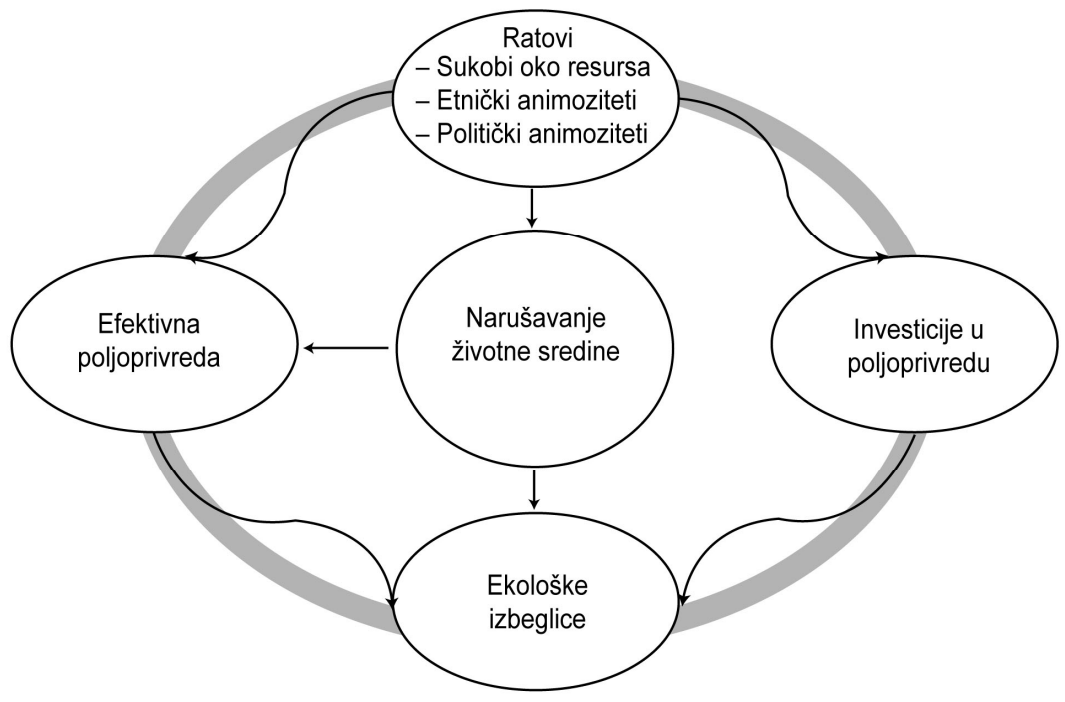

(Izvor: Epule et al., 2015)

S obzirom da se u narednim decenijama očekuje porast broja svetskog stanovništva (preko 9 milijardi do 2050. godine), za očekivati je da će takav trend najverovatnije dovesti do porasta broja ekoloških izbeglica u svetu, pogotovo u onim regionima u kojima je danas izražena njihova pojava. Imajući u vidu ovu činjenicu, kao i podatke o porastu broja prirodnih nesreća izazvanih klimatskim promenama, to će usloviti smanjenje raspoloživih prirodnih resursa neophodnih za normalan ljudski život [8]. U tom smislu, evidentno je kakve implikacije porast broja ekoloških izbeglica može imati na intenziviranje sukoba u budućnosti.

\section{Trendovi rasta broja ekoloških izbeglica}

Vrlo je teško sa velikom sigurnošću i preciznošću predvideti budući broj ekoloških izbeglica u svetu upravo zbog mnoštva faktora koji utiču na povećanje, odnosno smanjenje njihovog broja. Opšte je prihvaćeno stanovište da su ubrzane klimatske promene, porast ljudske populacije, porast broja siromašnih i pojačani procesi urbanizacije najznačajniji činioci koji će uticati na broj ekoloških izbeglica u svetu u narednom periodu. ${ }^{1}$

\footnotetext{
${ }^{16} \mathrm{U}$ stručnoj literaturi susreću se tri moguća scenarija u vezi sa budućnošću klimatskih promena koji se kreću od apokaliptičkih do uveravanja da neće doći do katastrofalnih posledica. Videti detaljnije u: Dimitrijević, D. (2010) Trendovi ekološke bezbednosti u XXI veku. Beograd: Fakultet bezbednosti, str. 60-64.
} 
Evidentno je da je u zemljama Trećeg sveta najveća stopa prirodnog priraštaja, kao i stopa smrtnosti. S obzirom na veliki broj stanovnika u zemljama Trećeg sveta, ${ }^{17}$ povećava se i potražnja za resursima kojih nema dovoljno.

Prema izveštaju UN "Perspektiva svetske populacije, revizija, ključni nalazi i tabele" (World population prospects: The 2015 revision, key findings and advance tables) ${ }^{18}$ iz 2015. godine, u svetu će do 2050. godine biti između 8,5 i 9,7 milijardi ljudi, za razliku od današnjih 7 milijardi. Takođe se navodi da će do 2100. godine svet naseljavati oko 11,2 milijardi ljudi pri čemu će nakon 2050. Afrika biti jedini region koji će beležiti konstantan rast populacije, što znači da će 2100. Afriku naseljavati 39\% ukupnog svetskog stanovnišva. ${ }^{19} 20$ Posebno će doći do eksplozije broja stanovnika u onim regionima u kojima su već danas prepoznati ekološki problemi kao što je predeo podsaharske Afrike, Centralne Amerike i indijskog potkontinenta. U proseku, migracije prema Severnoj Americi, Evropi i Okeaniji su u periodu 2000-2015. godine brojale 2,8 miliona ljudi godišnje.

Sternov izveštaj iz 2006. godine i Peti izveštaj Međunarodnog panela o klimatskim promenama (Intergovernmental Panel on Climate Change - IPCC) ${ }^{21}$ iz 2014. godine, predviđaju klimatske promene koje će do kraja XXI veka pogoditi sve regione na planeti. Obilujući grafikonima, tabelama i dijagramima, ovi izveštaji sumiraju da će klimu na Zemlji odlikovati porast prosečnih temperatura, kao i rast intenziteta i učestalosti ekstremnih vremenskih događaja poput suša i poplava. Porast prosečne srednje globalne godišnje temperature prouzrokovaće velike promene u klimatskom sistemu, što će za posledicu imati ubrzano topljenje glečera i stalnog snežnog pokrivača na visokim planinama i polovima, porast nivoa mora, učestalije suše u pojedinim regionima, povećanje padavina i poplava, tropskih oluja, kao i smanjenje resursa pijaće vode širom sveta. Porast temperatura, rast nivoa mora i sve učestalije ekstremno vreme imaće direktan uticaj na život ljudi, tržište i ukupnu ekonomiju. Jasno je da će ove promene, u zavisnosti od stepena intenziteta, uticati na porast broja ekoloških izbeglica, ${ }^{22}$ pogotovo u onim regionima gde je već danas evidentan njihov veliki broj.

Sahelska Afrika i Rog Afrike predstavljaju nesumnjivo najveći izvor ekoloških izbeglica u svetu. Međutim, ni indijski potkontinent nije lišen ovog sve većeg problema. Pozivajući se na Hua i Miklina (Hu, 1993; Micklin, 1993), Ostojić napominje da na prostoru NR Kine, među ukupnim brojem izbeglica (120 miliona), čak 6 miliona treba da ima status ekoloških iz-

\footnotetext{
${ }^{17}$ Prema podacima Odeljenja za ekonomska i socijalna pitanja Ujedinjenih nacija (The United Nations Department of Economic and Social Affairs - UN DESA), u Indiji, npr. kao državi Trećeg sveta, broj stanovnika se uvećava za $1,2 \%$ na godišnjem nivou, pri čemu taj procenat za urbano stanovništvo iznosi $2,4 \%$ u istom periodu. Džepna statistička knjiga UN-a za 2017. godinu dostupna je na sledećoj internet adresi: https://unstats.un.org/unsd/publications/pocketbook/files/world-stats-pocketbook-2017.pdf

${ }^{18}$ Izveštaj je dostupan na sledećoj internet adresi: http://esa.un.org/unpd/wpp/publications/files/key_findings_wpp_2015.pdf

${ }^{19} \mathrm{U}$ izveštaju se takođe navodi 9 zemalja u kojima se, u periodu 2015-2050. godine, očekuje rast polovine svetske populacije: Indija, Nigerija, Pakistan, DR Kongo, Etiopija, Tanzanija, SAD, Indonezija i Uganda.

${ }^{20}$ Jasno je kakve bezbednosne implikacije mogu imati ovakvi trendovi, naročito kada se uzme u obzir da je najveći deo populacije ekoloških izbeglica poreklom iz Sahelskog dela Afrike.

${ }^{21}$ Izveštaj je dostupan na sledećoj internet adresi: http://www.ipcc.ch/pdf/assessment-report/ar5/wg3/ipcc_wg3_ar5_full.pdf

${ }^{22}$ Takvo jedno predviđanje daje i Robert Nikols (Robert Nicholls) koji ističe da će u periodu do 2080. godine nastati između 50 i 200 miliona ekoloških izbeglica (2004).
} 
beglica buduću da su primorani da napuste svoje domove usled agresivne izgradnje urbane infrastrukuture[8]. Prema preliminarnim procenama utemeljenim na gorepomenutim izveštajima, porast nivoa mora rezultiraće najvećim brojem ekoloških izbeglica i to u onim državama koje se nalaze uz more i čija prosečna nadmorska visina nije velika. Procenjuje se da će najteže stanje po tom pitanju biti upravo u NR Kini i to u njenoj primorskoj zoni u kojoj su smešteni višemilionski gradovi. Slično stanje zadesiće i Bangladeš čije se $80 \%$ teritorije nalazi u delti reke Gang. Na taj način, ova država izgubiće oko 10\% svoje teritorije što će prouzrokovati veliki rast broja ekoloških izbeglica. Takođe, usled porasta nivoa mora, velika opasnost preti i koralnim ostrvima u Indijskom i Tihom okeanu.

Kako Ostojić navodi, još jedan veliki problem sa kojim će se globalno stanovništvo susresti do kraja ovog veka tiče se nedostatka resursa pijaće vode[8][27]. Naime, porast srednjih godišnjih temperatura i ubrzano topljenje glečera i snega na visokim planinama za posledicu će imati smanjenje protoka velikih reka. Svakako da su ovim najviše pogođeni oni regioni koji i danas imaju problema sa dovoljnim resursima pijaće vode, poput podsaharske Afrike. Nedostatak dovoljnih zaliha pijaće vode umanjiće količinu proizvedene hrane što će posredno uticati na povećanje broja ekoloških izbeglica. Osim toga, činjenica je da najveći broj ekoloških izbeglica dolazi iz najsiromašnijih zemalja čije ekonomije u prvom redu zavise od poljoprivredne proizvodnje koja je najpodložnija uticaju klimatskih faktora. Siromašne i ruralne sredine nemaju uslova za korišćenje adekvatnih i testiranih agrotehničkih sredstava, što dovodi do ugrožavanja zemljišta i stvaranja neplodnosti.

Pored ovakvih predviđanja, imajući u vidu novija temetizovanja problema ekoloških izbeglica koja in dovode u vezu sa konceptom otpornosti, sa pravom se postavlja i pitanje adekvatnosti kapaciteta stanovništva za odgovor na ovakve promene. Jer, kako Ruveni navodi, ključno pitanje nije koliko je jedna katastrofa jaka sama po sebi, već koliko su ljudi jaki i sposobni da se izbore sa istom [25].

\section{Moguća rešenja problema}

Degradacija životne sredine ima za posledicu kumulativne društvene efekte kao što su kretanje stanovništva, pad ekonomije i slabljenje države. Takvo stanje stvari može se negativno odraziti ne samo na opšte stanje u jednoj državi, već i na međunarodnu bezbednost u smislu moguće eskalacije konflikata. Stopa i obim tih konflikata će se povećavati kako degradacija životne sredine sve više uzima maha [28]. Sa tim u vezi, od velikog je značaja da međunarodna zajednica adekvatno reaguje na ovo pitanje.

S obzirom na kompleksnost samog fenomena ekoloških izbeglica, postoje najrazličitije preporuke koje bi se mogle razmatrati kao rešenja postojećeg problema. One se odnose kako na preventivne opcije, usmerene ka sprečavanju ekološki indukovanih migracija, tako i na opcije kojima bi se mogao smanjiti broj ekoloških izbeglica (metode pretežno reaktivnog karaktera). Stoga ne čudi zašto su klimatske promene i ekološke izbeglice (kao jedna od njihovih posledica) jedna od najznačajnijih tema brojnih međunarodnih konferencija, seminara, naučnih skupova, foruma i sl. Kao krucijalni koraci u procesu rešavanja ovog problema u literaturi se ističu neophodnost definisanja ekoloških izbeglica i razvoj odgovorajućih politika koje bi na adekvatan način odgovorile na ovu pojavu. 
Pomeranjem rasprave o klimatskim promenama (a samim tim i ekološkim izbeglicama) na nivo UN, ovom problemu pridaje se međunarodni značaj. Pored toga, neophodno je doneti nove međunarodne sporazume o migraciji, naročito ako se ima u vidu da je postojeća Konvencija UN o izbeglicama zastarela i, kao takva, dovodi do neujednačenog tumačenja i primene politikih rešenja. $S$ obzirom da je adekvatna pravna zaštita osnova međunarodnog režima izbeglica, preporuke u vezi sa ovim pitanjem kreću se od potrebe za revizijom postojeće Konvencije preko kreiranja potpuno nove konvencije do sprovođenja mera privremene zaštite ekoloških izbeglica. Pored pravnih izazova koje treba rešiti u narednom periodu kako bi se ovo pitanje pozicioniralo unutar normativnih i institucionalnih okvira, neophodno je rešiti i određena tehnička pitanja poput monitoringa ekoloških izbeglica[29], odnosno uspostavljanja jedinstvene baze podataka o osobama koje migriraju usled ekoloških faktora.

Preventivne (proaktivne) mere u cilju sprečavanja ekološki indukovanih migracija podrazumevaju obezbeđenje adekvatnih uslova za život u postojećim domovinama. U vezi sa tim, Majers i Kentova u delu Environmental exodus: an emergent crisis in the global arena, navode nekoliko takvih pristupa poput prepoznavanja korena problema, promovisanja održivog razvoja, pružanja inostrane pomoći, posebnih inicijativa za zemlje u razvoju i sl. ${ }^{23}$ Autori svoje izlaganje zaključuju stavom kako je za sve zemlje, nezavisno je li reč o razvijenoj državi ili državi u razvoju, najvažniji cilj smanjiti motivaciju ekoloških izbeglica za napuštanjem svojih domova kroz promociju održivog razvoja u svim sferama ljudskog života. Tako je, generalno posmatrano, na razvijenim zemljama da odluče hoće li rizičnim zemljama pomoći u obezbeđivanju sredstava neophodnih za kvalitetan život ili će se u protivnom suočiti sa sve većim brojem ekoloških izbeglica iz zemalja u razvoju [1].

Još jedno zapažanje koje iznose autori u vezi sa preporukama i mogućim rešenjima ovog problema tiče se ukorenjenih navika istraživača u oblastima migracija i ekoloških nauka. Naime, dok mnoge klasične teorije o migracijama karakteriše zanemarivanje (degradacije) životne sredina kao vrlo značajnog katalizatora migratornih kretanja, teorije o ekološkom upravljanju uglavnom nastoje da skrajnu takva kretanja u drugi plan. [9] Prema ovim autorima, prevazilaženje takvog jaza predstavlja prvi korak u rešavanju ovog problema.

Dejana Dimitrijević, govoreći o ublažavanju rizika u vezi sa izbeglicama i potencijalnim sukobima usled degradacije životne sredine, predlaže sledeće korake: izmeštanje izbeglica dalje od zone sukoba (posebno pograničnih regiona); sprečavanje infiltracije oružja i boraca u civilne izbegličke zajednice i kampove; obezbeđivanje smislene alternative vezane za položaj izbeglica koja bi dozvolila produktivno zapošljavanje i podsticanje dijaloga sa lokalnim zajednicama u smislu prevazilaženja ekonomskih i socijalnih problema oblasti koje primaju izbeglice [15]. Autorka takođe dalje obrazlaže neophodnost podizanja javne svesti lokalnog stanovništva o problemu izbeglica i revizije zakona i drugih propisa kojima bi se izbeglice lakše integrisale u sredinu u koju su došle, a sve u cilju sprečavanja neprijateljstava između izbeglica i građana zemlje „domaćina”.

Jedno je jasno: fenomen ekoloških izbeglica jeste globalni problem i kao takav je, manje ili više, prepoznat na nivou međunarodne zajednice. S obzirom na implikacije koje ima i/ili može imati po međunarodnu bezbednost, nužno zahteva urgentnu intervenciju na nivou međunarodne zajednice i uspostavljanja adekvatne međunarodne politike.

\footnotetext{
${ }^{23}$ Videti detaljnije u: Myers, N. \& Kent, J. (1995). Environmental Exodus: an Emergent Crisis in the Global Arena. Washington DC: Climate Institute, 154-160 str.
} 


\section{Zaključak}

Porast broja svetskog stanovništva i sve učestalije i ubrzane klimatske promene dovele su do pojave nove vrste izbeglica - ekoloških izbeglica. Odnos između ove dve promenljive sve više se usložnjava te se (iako ne sasvim nužno) uočava pravilnost da usled degradacije životne sredine dolazi i do migracija stanovništva iz područja pogođenih ekološkim promenama. Uzročno-posledična priroda ovakve veze skopčana je i sa brojnim drugim socio-ekonomskim teškoćama sa kojima se suočavaju savremene države i međunarodna zajednica.

Prema procenama brojnih relevantnih naučnika i međunarodnih institucija iz ove oblasti, u narednim godinama očekuje se porast broja ekoloških izbeglica u svetu, što će imati raznolike implikacije kako po nacionalnu bezbednost države koja predstavlja njihovu krajnju destinaciju, tako i po bezbednost na međunarodnom nivou.

Kao glavni izazovi koji stoje pred međunarodnom zajednicom u kontekstu rešavanja pitanja ekoloških izbeglica mogu se izdvojiti nepostojanje opšteprihvaćene definicije ovog koncepta (kako na akademskom, tako i praktično-političkom nivou), nepostojanje jedinstvenog pravnog okvira i politike kojima bi se upravljalo ovom pojavom na lokalnom, nacionalnom, regionalnom i međunarodnom nivou, demografski i klimatski trendovi koji direktno utiču na intenziviranje ove pojave, nepostojanje jedinstvenih i sistematskih analiza i procena i mnogi drugi. Sa tim u vezi, ukoliko se u narednom periodu ne deluje sistematski i koordinisano, problem će postati kompleksniji, a bezbednosni rizici sve izvesniji. Upravo iz tog razloga je neophodno da međunarodna zajednica uloži zajedničke napore u cilju jačanja svesti i rešavanja ovog globalnog problema.

\section{Literatura}

[1] Myers, N. \& Kent, J, Environmental Exodus: an Emergent Crisis in the Global Arena, Climate Institute, Washington DC, 1995.

[2] Myers, N, Environmental refugees: a growing phenomenon of the 21st century, Philosophical Transactions of the Royal Society of London B: Biological Sciences 357(1420), 2002, 609-613.

[3] Piguet, E, Climate Change and Forced Migration, New Issues in Refugee Research UNHCR working pp: 153, 2008.

[4] Gemenne, F, One good reason to speak of'climate refugees', Forced Migration Review, 49, 2015, 70-71.

[5] Jovanović-Popović, D, i Milinčić, M. A, Coonceptualization of environmental refugees. Demografija - međunarodni časopis za demografska i ostala društvena istraživanja, 13, 2016, 69-82.

[6] El-Hinnawi, E, Evnironmental Refugees, United Nations Environmental Programme, Nairobi, 1985.

[7] Jacobson, J, Environmental refugees: a yardstick of habitability, Worldwatch paper 86, Worldwatch Institute, Washington, DC, 1988.

[8] Ostojić, G. D, Ekološke izbeglice - direktan ili indirektan put do konflikta. Vojno delo, 66(1), 2014, 51-83.

[9] Dun, O. \& Gemenne, F, Defining 'environmental migration'. Forced Migration Review, 31 (October), 2008, 10-11. 
[10] Konvencija o statusu izbeglica, UN, 1967, http://www.unhcr.org/3d9abe177.html pristupljeno (20.1.2018).

[11] Conisbee, M., \& Simms, A, Environmental refugees: The case for recognition, New Economics Foundation, London, 2003, 17-18.

[12] Williams, A, Turning the tide: recognizing climate change refugees in international law. Law \& Policy, 30(4), 2008, 502-529.

[13] Docherty, B., \& Giannini, T, Confronting a rising tide: a proposal for a convention on climate change refugees, Harv. Envtl. L. Rev, 33, 2009, 349.

[14] Tepavac, D. N, Migrations of population as a consequence of ecological and environmental security violation, Vojno delo, 68(6), 2016, 83-99. 2010.

[15] Dimitrijević, D, Trendovi ekološke bezbednosti u XXI veku, Fakultet bezbednosti, Beograd,

[16] Lee, S.-wha, In Limbo: Environmental Refugees in the Third World, Conflict and the Environment, 1997, 273-292.

[17] Methmann, C., \& Oels, A, From 'fearing'to 'empowering'climate refugees: Governing climate-induced migration in the name of resilience, Security Dialogue, 46(1), 2015, 51-68.

[18] Bettini, G, Climate barbarians at the gate? A critique of apocalyptic narratives on 'climate refugees', Geoforum, 45, 2013, 63-72.

[19] Brzoska, M., \& Fröhlich, C, Climate change, migration and violent conflict: vulnerabilities, pathways and adaptation strategies. Migration and Development, 5(2), 2016, 190-210.

[20] Drury, A. C., \& Olson, R. S, Disasters and political unrest: An empirical investigation. Journal of Contingencies and Crisis Management, 6(3), 1998, 153-161.

[21] United Nations Security Council. (2007). Debate on impact of climate change on peace, security. Security council, 5663rd meeting, New York, NY.

[22] United Nations General Assembly (UNGA). (2009). Climate Change and its possible security implications. A, RES, 63, 281, New York, NY.

[23] Gleditsch, N. P, Whither the weather? Climate change and conflict. Journal of Peace Research, 49, 2012, 3-9.

[24] Pavlović, S, (Ne)opravdanost sekurizizacije životne sredine, Bezbednost, 1/2017, 2017, 137-149.

[25] Reuveny, R, Climate change-induced migration and violent conflict, Political Geography, 26 (6), 2007, 656-673.

[26] Epule, T. E., Peng, C., \& Lepage, L, Environmental refugees in sub-Saharan Africa: a review of perspectives on the trends, causes, challenges and way forward. GeoJournal, 80(1), 2015, 79-92.

[27] Ostojić, G. D, Kontrola resursa pijaće vode kao izvor regionalnih sukoba, Fakultet bezbednosti, Beograd, doktorska disertacija, 2016.

[28] Homer-Dixon, T, Environmental scarcities and violent conflict: evidence from cases, International Security, 19(1), 1994, 5-40.

[29] Osterhus, L. (2015). The Need for International Policy for Environmental Refugees. 